\title{
Karakterisasi Akuifer Berumur Miosen di Daerah Geologi Kompleks Thrust Fault Zona Kendeng dengan Fisika Batuan dan Tomografi
}

\section{Resistivitas}

\author{
Bagus Endar B. Nurhandoko ${ }^{1, *}$, Kaswandhi Triyoso ${ }^{2}$, M. Rizka A. Hadi ${ }^{2}$, Insan Rizal², \\ Djedi S. Widarto ${ }^{3}$, Nurhasan ${ }^{1}$ \\ ${ }^{1}$ Kelompok Keahlian Fisika Bumi dan Sistem Kompleks FMIPA ITB \\ ${ }^{2}$ Rock Fluid Imaging Lab Bandung \\ ${ }^{3}$ Prodi Teknik Geofisika, Universitas Pertamina, Jakarta 12220 \\ *Email: bagusnur@bdg.centrin.net.id
}

\begin{abstract}
Abstrak: Kondisi geologi Kawasan Kendeng tergolong kompleks dengan dominasi lapisan tua, lapisan lempung yang berlimpah, dan struktur sesar berarah naik (thrust fault) yang intensif. Fenomena ini menimbulkan masalah kelangkaan air serta kesulitan penyediaan air bersih di daerah ini. Salah satu potensi akuifer potensial di daerah ini adalah batuan karbonat klastik napal berumur Miosen. Karbonat klastik ini merupakan bagian dari Formasi Kerek. Data pengukuran laboratorium, hasil survei dan serangkaian analisis menyimpulkan bahwa wilayah studi ini masih memiliki potensi akuifer. Metode tomografi resistivitas telah berhasil mencitrakan sejumlah lokasi akuifer air tanah yang potensial meskipun wilayah tersebut didominasi oleh dengan strukturstruktur berarah tegak. Analisis akuifer pada penelitian ini meliputi pengukuran laboratorium fisika batuan, pengukuran sudut kontak, dan pengukuran resistivitas tomografi di lapangan. Hasil pengamatan lapangan dan pencitraan bawah permukaan menunjukkan bahwa akuifer Napal ini dikelilingi oleh lapisan lempung Miosen yang kedap air. Namun hasil pengukuran laboratorium menunjukkan bahwa sudut kontak air ke Napal Kerek ini ini selalu kurang dari 90 derajat, oleh karenaya air dalam pori napal cenderung merambat keatas oleh fenomena tekanan kapilarisasi. Fenomena sistem kapiler ini menunjukkan bahwa akuifer napal karbonat Formasi Kerek cenderung menjadi akuifer yang baik. Fenomena di lapangan membuktikan bahwa singkapan napal yang digali menjadi sumur di daerah rendahan selalu menunjukkan keberadaan air. Rekomendasi penentuan titik pemboran air di kawasan ini sebaiknya menargetkan zona porositas tinggi napal karbonat jenuh air yang dapat diperoleh dari tomografi resistivity, serta memperhatikan arah struktur supaya sumur dapat menembus lebih banyak lapisan akuifer napal. Kata kunci: zona sesar naik Kendeng, karakterisasi akuifer, tomografi resistivitas, contact angle, Fisika Batuan
\end{abstract}

Abstract: The geological conditions in the Kendeng Zone are complex with the dominance of ancient layers, the abundance of clay layers, and the high-intensive thrust fault structures. These phenomena generate a problem of water scarcity and the difficulty of freshwater supply.
One of the potential aquifers in this area is Miocene marl clastic carbonate rocks. This marl clastic carbonate is a part of the Kerek Formation. Laboratory measurement data, survey results, and a series of analyzes conclude that this study area still has some aquifers potential. The resistivity tomography method has succeeded in imaging some potential groundwater aquifer locations even though thrust faulting layers dominate the region. Aquifer analysis in this study covers rocks physics laboratory measurement, measuring the contact angle, and measuring the resistivity of tomography in the field. The field observation and subsurface imaging results show an impermeable Miocene clay layer surrounds the marl aquifer. However, the measurement results show the contact angle between water and marl is always less than 90 degrees which the water tends to be lifted upwards by capillary pressure phenomena. This capillary system phenomenon indicates that the marl carbonate aquifer of the Kerek Formation tends to become a good aquifer. Field phenomena prove that wells dug in the marl outcrops in the low areas always contain water. The recommendation for determining the point of water drilling in this area should target the wet high porosity zone of marl carbonate, which can be obtained from resistivity tomography. We should consider the structure's direction so that the well can penetrate more layers of the marl aquifer.

Keywords: Thrust fault Kendeng, aquifer characterization, resistivity tomography, contact angle, rock physics

\section{PENDAHULUAN}

Kondisi daerah sekitar Zona Kendeng, Kabupaten Sragen mempunyai kendala besar dalam penyediaan air bersih dari akuifer air tanah untuk kebutuhan sehari-hari. Hal ini disebabkan oleh kondisi geologi bawah permukaan yang cukup komplek dan berada pada thrust faulted zone dan berumur Miosen (Sukardi dan Budhitrisna, 1992), sehingga keberadaan akuifer air tanah pada daerah ini menjadi sangat kompleks. 


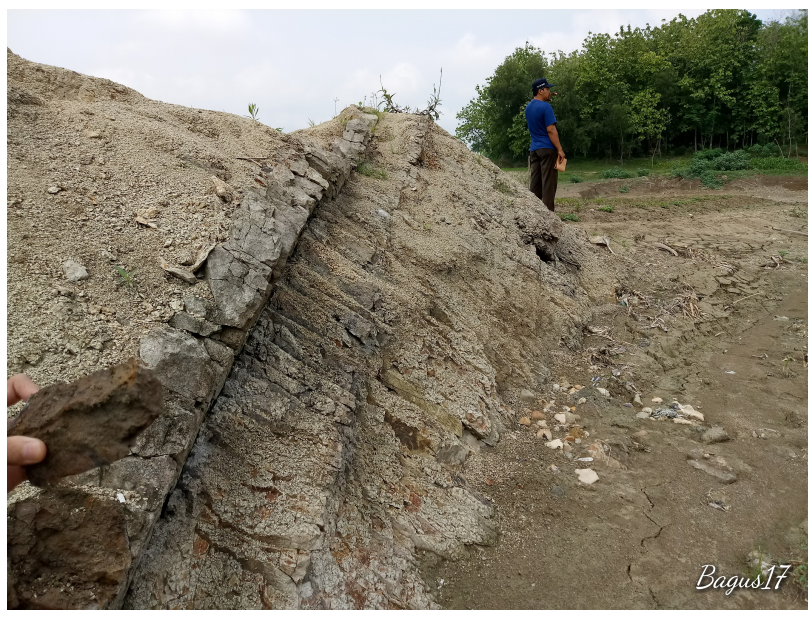

Gambar 1. Kondisi Daerah Penelitian Berada Pada Thrust Faulted Zone.

Secara umum, struktur - struktur yang ada di Zona Kendeng berupa lipatan lipatan, sebagian besar dari lipatan tersebut berupa lipatan asimetri bahkan beberapa ada yang berupa lipatan overturned akibat berada pada thrust faulted zone. Zona thrust faulted ini mengakibatkan kondisi perlapisan batuan yang ekstrim vertikal sehingga mengakibatkan kondisi akuifer-akuifer air tanah juga hampir tegak atau vertikal (Gambar 1).

Curah hujan pada daerah penelitian cukup tinggi yaitu $2109 \mathrm{~mm}$ per tahun, dengan rentang curah hujan bulanan antara $55 \mathrm{~mm} /$ bulan pada bulan terkering dan bisa lebih dari $400 \mathrm{~mm} /$ bulan pada bulan terbasah, pada bulan Desember 2020 memperlihatkan data curah hujan ekstrim hingga mencapai $500 \mathrm{~mm} /$ bulan (BMKG, 2021). Data curah hujan yang cukup tinggi ini memperlihatkan bahwa seharusnya terdapat akuifer-akuifer air tanah yang memiliki cadangan yang cukup besar. Namun demikian, batuan yang berpotensi sebagai akuifer sebarannya cukup kompleks dikarenakan keberadaan sesar-sesar naik. Penelitian ini menggunakan metode tomografi resistivitas dan analisa laboratorium rock physics untuk mengidentifikasi keberadaan akuifer bawah tanah pada kondisi geologi yang cukup kompleks di daerah ini.

Metoda tomografi resistivitas bekerja menggunakan sifat-sifat kelistrikan yang diterapkan pada batuan bawah permukaan untuk mengidentifikasi akuifer air tanah pada daerah-daerah dengan kompleksitas geologi bawah permukaan yang tinggi (Arora dan Ahmed, 2011; Daily dkk., 1992; Gan dkk., 2017; Kumar dan Rai, 2011; Martínez dkk., 2009; Redhaounia dkk., 2016, 2015; Tassy dkk., 2014). Kompleksitas akuifer ini meliputi beragam sebab seperti akuifer berada pada zona retakan granit (Arora dan Ahmed, 2011), akuifernya adalah vadose zone dari batu gamping (Gan dkk., 2017; Redhaounia dkk., 2016) ataupun pada kanal sungai yang rumit (Martínez dkk., 2009).

Penelitian pencarian air bawah tanah di daerah sulit air di Indonesia menggunakan geoelektrik di batuan karbonat formasi berumur tua juga pernah dilakukan diantaranya (Puradimaja dkk., 2006), penelitian ini dilakukan di daerah karbonat yang sulit air di Sukabumi selatan.

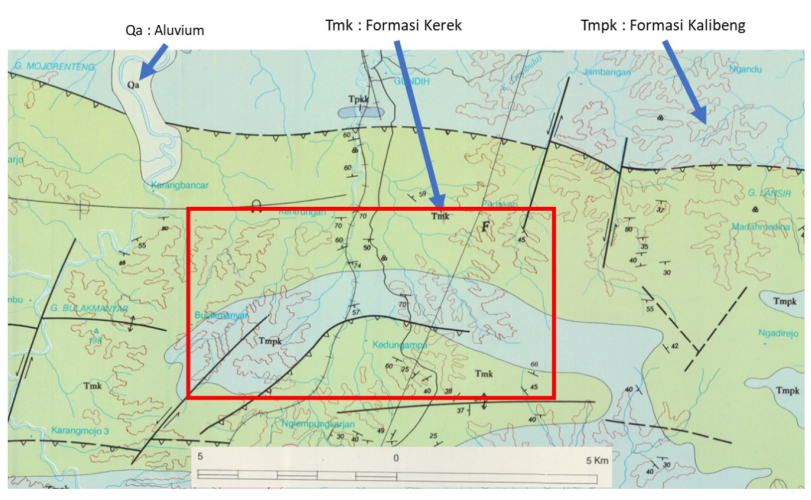

Gambar 2. Peta Geologi Daerah Penelitian (Sukardi dan Budhitrisna, 1992).

\section{GEOLOGI DAERAH PENELITIAN}

Kondisi geologi pada daerah penelitian sebagian besar terdiri dari Formasi Kalibeng berdasarkan peta Geologi (Gambar 2) yang dikeluarkan oleh Departemen Energi dan Sumber Daya Mineral,(Sukardi dan Budhitrisna, 1992), yang tersusun atas Napal pejal di bagian atas, Napal bersisipan batu pasir tufan dan bintal batu gamping di bagian bawah, serta Formasi Kerek yang tersusun atas batuan sedimen tipe flysch pada bagian bawah yang berlapis sangat baik, terdiri dari persilangan batu lanau, batu lempung, batu pasir gampingan dan batu gamping pasiran, mengandung bahan gunung api; bagian atas napal bersisipan batu pasir tufaan-gampingan, batu lanau tufaan dan batu pasir kerikilan; mengandung bahan gunung api. Daerah Kendeng ini dikenal sangat kompleks, terdominasi struktur tegak, dan mengandung banyak variasi fenomena geologi seperti bukit, semburan lumpur, maupun sumber air panas (Nurhandoko dkk., 2019).

Gambar 3 memperlihatkan kondisi hidrogeologi daerah penelitian. Daerah penelitian terletak pada akuifer produktif sedang dengan penyebaran setempat, kemenerusan rendah serta debit kurang dari 5 liter / detik. Hasil survey ini diharapkan dapat membantu dalam penentuan lokasi sumur bor dengan suplai air yang cukup banyak untuk kegiatan seharihari masyarakat sekitar maupun untuk kegiatan pertanian. Adapun masyarakat sekitar yang telah melakukan pengeboran sumur untuk mendapatkan akuifer umumnya mengalami kendala berupa minimnya suplai air pengisi akuifer sumur yang telah dibor. Sejumlah lahan pertanian bahkan harus mengalami kekeringan akibat tidak adanya suplai air yang cukup, terutama pada saat musim kemarau tiba.

\section{AKUISISI DATA TOMOGRAFI RESISTIVITAS}

Akuisisi data Tomografi resistivitas dimaksudkan untuk memberikan gambaran yang lebih lengkap bawah permukaan, yang kondisi permukaannya bisa jelas terlihat dari singkapan sesar naik seperti pada Gambar 1. Pengambilan data tomografi resistivitas menggunakan perangkat pengukuran TomoResIP-3100 Multichannel (Gambar 4) yang dikembangkan di laboratorium penelitian di Indonesia (Nurhandoko, 2019b) dan telah mengalami beberapa pengembangan lebih lanjut untuk pengukuran dengan target sa- 


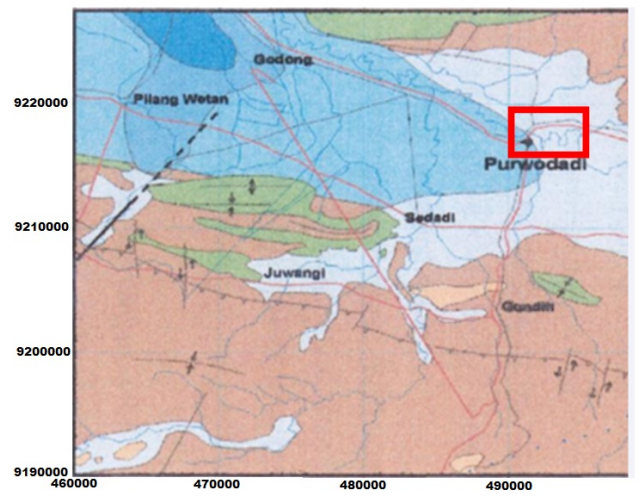

Keterangan :

Akuifer dengan aliran ruang antar butir

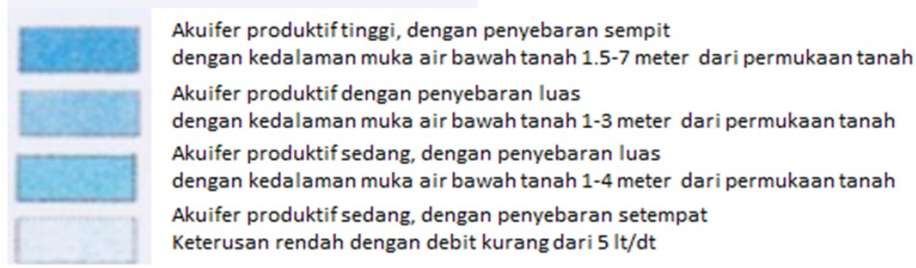

Akuifer dengan aliran celahan dan ruang antar butir

Setempat, akuifer produktif kecil dengan kedalaman muka air bawah tanah $3-6$ meter dari permukaan tanah

Akuifer (bercelah atau sarang) produktif kecil dan daerah air bawah tanah langka

Daerah air tanah langka, kedalaman muka air bawah tanah 6-8 meter dari permukaan tanah

Akuifer produktif kecil, penyebaran setempat

Dengan kedalaman muka air bawah tanah 1-5 meter dari permukaan tanah

Gambar 3. Kondisi Hidrogeologi Daerah Penelitian

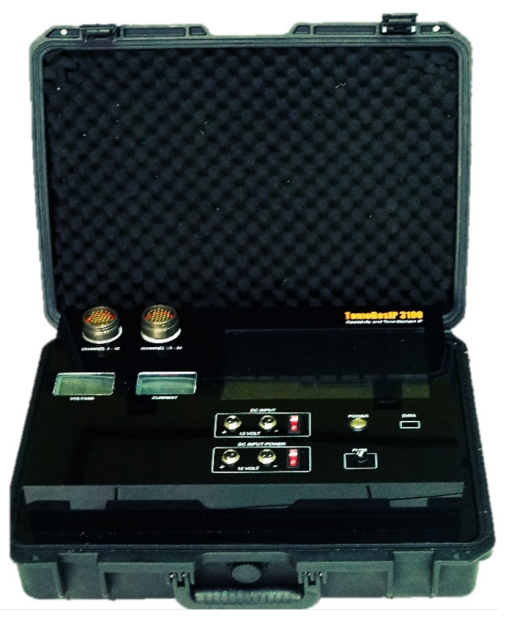

Gambar 4. Perangkat Pengukuran Tomografi Resistivitas TomoResIP-3100

ngat dalam (1000 meter) dan bentangan yang sangat lebar (> 3000 meter) yang terkontrol secara nirkabel (Nurhandoko, 2019b). Konfigurasi pengukuran yang digunakan adalah Wenner Schlumberger dan Wenner Alfa.

Dengan penggunaan perangkat ini, seluruh elektroda dapat langsung dibentangkan untuk menghasilkan citra bawah permukaan dengan lebih cepat dan akurat. Pada penelitian ini digunakan elektroda sebanyak 24 channel dengan bentangan hingga 300 meter. Perangkat TomoResIP-3100 ini juga sudah teruji penggunaannya untuk eksplorasi akuifer (Virman dan Nurhandoko, 2016) baik untuk kegiatan penelitian maupun kegiatan pengabdian masyarakat (Nurhandoko, 2018, 2019a; Nurhandoko dkk., 2019).

Akuisisi data dilakukan di daerah jawah tengah disekitar zona Kendeng dengan memiliki keadaan geologi yang memiliki trust fault. Lintasan di desain supaya memotong arah sesar naik dengan posisi lintasan survey berada pada tabel-1. Hal ini dimaksudkan untuk mengetahui secara lebih akurat lagi posisi dan bentuk akuifer bawah permukaannya. Lintasan survey pada penelitian ini berjumlah 2 lintasan seperti ditunjukkan pada Gambar 5. Kedua lintasan ini me-
Tabel 1. Koordinat Lokasi Lintasan dan Elektroda.

\begin{tabular}{cccc}
\hline Lintasan & Elektroda & Koordinat X & Koordinat Y \\
\hline \multirow{2}{*}{1} & 1 & 0485274 & 9193388 \\
& 12 & 0485256 & 9193288 \\
& 24 & 0485248 & 9193170 \\
\hline \multirow{2}{*}{2} & 1 & 0484592 & 9192897 \\
& 12 & 0484547 & 9192786 \\
& 24 & 0484506 & 9192865 \\
\hline
\end{tabular}

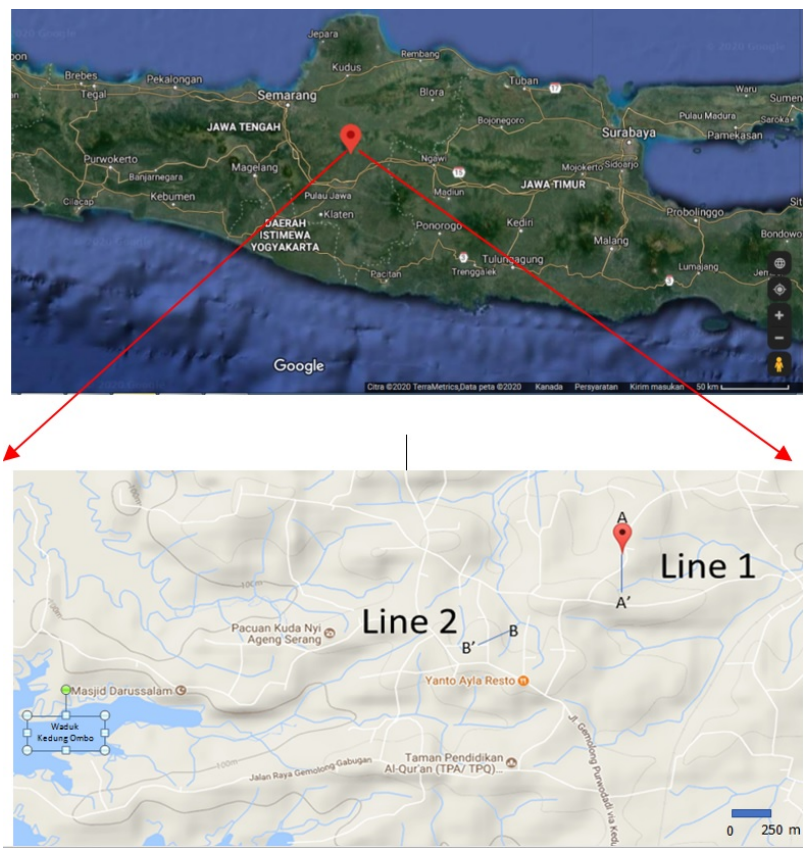

Gambar 5. Peta Lokasi Lintasan Survey di daerah sulit air thrust fault zona Kendeng di daerah Jawa Tengah.

miliki kondisi berupa daerah persawahan dan perbukitan seperti ditunjukkan pada Gambar 6 dan Gambar 7 . 


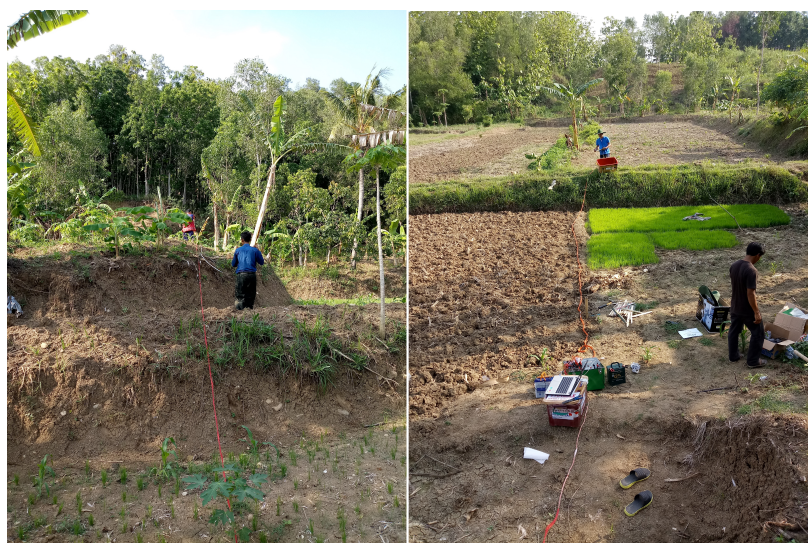

Gambar 6. Keadaan lintasan 1 pada saat survey berlangsung

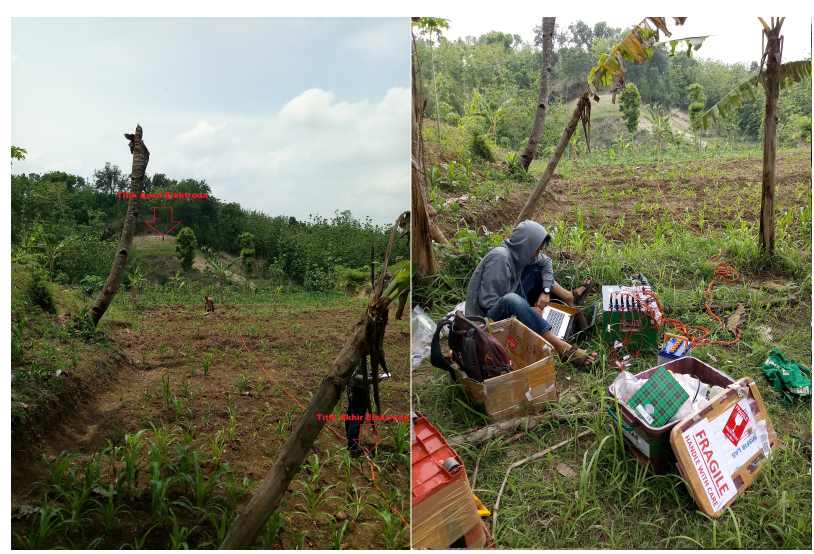

Gambar 7. Keadaan lintasan lintasan 2 saat survey berlangsung.

\section{UJI LABORATORIUM FISIKA BATUAN}

Pengetahuan tentang karakater reservoir dapat dianalisa dari informasi sudut kontak, beberapa peneliti telah melakukan studi antara sudut kontak dan karakter reservoir (Bachmann dkk., 2007, 2000; Wang dan Wallach, 2020). Pada penelitian ini dilakukan pengukuran sampel di laboratorium fisika batuan untuk mengetahui sudut kontak (contact angle) dari air terhadap batuan pada berbagai jenis sampel di daerah ini. Jumlah sampel yang dilakukan pengukuran sudut kontak sebanyak 2 buah sampel seperti ditunjukkan oleh Gambar 8.

Metode pengukuran sudut kontak ini dilakukan dengan menggunakan mikroskop serta alat sampel titrasi berukuran mikro liter. Informasi sudut kontak antara sampel batuan lapangan dan air dapat digunakan untuk menentukan tekanan kapiler pada batuan seperti ditunjukkan oleh persamaan berikut.

$$
P_{c}=\frac{2 \sigma \cos \theta}{r}
$$

dengan,

$P_{c}=$ Tekanan Kapiler

$\sigma=$ Tegangan antar permukaan

$\theta=$ Sudut kontak

$r=$ Jari-jari

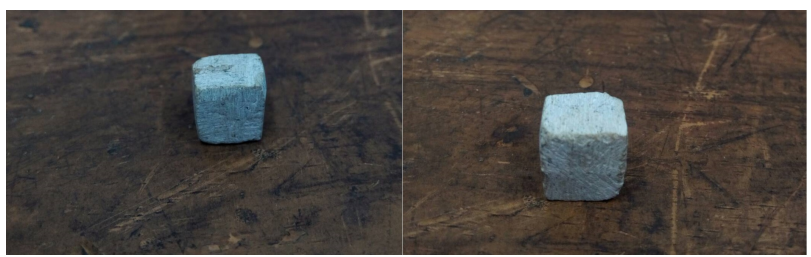

Gambar 8. Sampel Batuan Napal Carbonate Formasi Kerek untuk Pengukuran Sudut Kontak.

Sudut kontak yang kecil $(<900)$ menghasilkan tekanan kapiler yang tinggi sehingga dapat mengangkat air lebih tinggi menuju permukaan, sedangkan sudut kontak yang besar (>900) dapat membuat tekanan kapiler menjadi negatif dan menekan permukaan fluida menjadi ke permukaan yang lebih dalam seperti ditunjukkan pada Gambar 9 .

Pengukuran resistivitas dilakukan pada sampel batuan di laboratorium untuk mengetahui besarnya resistivitas batuan pada kondisi tidak tersaturasi air (kering) dan tersaturasi air (basah) sehingga bisa menjadi rujukan untuk membuat karakterisasi hasil inversi pengukuran resistivity dari lapangan.

Pengukuran resistivitas pada kondisi kering dilakukan dengan melakukan proses SWIRR (saturated water irreducible, yaitu sampel dikeringkan dengan gaya sentrifugal hingga tidak ada air yang keluar lagi dari sampel. SWIRR adalah kondisi setara dengan saturasi air minimum didalam sampel batuan yang dibatasi kadarnya oleh tekanan kapiler atau pori pada keadaan kosong (kering) tetapi matriks sampel masih terbasahi oleh air karena efek tekanan kapiler. Pengukuran pada kondisi basah dilakukan dengan mensaturasi sampel sampai pori terisi air $100 \%$.

Pengukuran resistivitas sampel batuan dari kerek formation untuk sample A pada kondisi basah (Wet) adalah 62 ohm.m, sedangkan dalam kondisi kering (Dry) adalah 330 ohm.m. Sampel batuan A ini memiliki bulir yang kasar. Sedangkan, resistivitas sample B pada keadaan basah (Wet) adalah 77 ohm.m, sedangkan dalam keadaan kering (Dry) adalah $=120$ ohm.m, Resistivitas sample $\mathrm{C}$ pada keadaan basah (Wet ) $=22$ ohm.m, dan pada keadaan kering (Dry) $=2800$ ohm.m) seperti ditunjukkan pada Gambar 10 .

Nilai resistivitas dalam keadaan basah dan kering pada pengukuran laboratorium dapat menjadi acuan untuk pengukuran hasil tomografi resistivitas. Kisaran harga di sampel dalam kedaan basah menunjukkan hasil di kisaran $22-77$ ohm.m, nilai resistivitas dari citra tomografi yang berada kurang daripada nilai laboratorium ini kemungkinan adalah lempung Miosen. Nilai resitivitas yang tinggi, diatas kisaran 120-300 ohm.m (ribuan ohm.m) merujuk hasil uji laboratorium fisika batuan kemungkinan besar adalah batuan kering.

\section{HASIL DAN PEMBAHASAN}

Posisi line-line survey dipilih di daerah rendahan supaya memiliki kemungkinan keberhasilan yang lebih besar dalam menemukan air. Hasil survey tomografi resistivitas yang telah dilakukan di daerah ini ditunjukkan dari penampangpenampang resistivitas untuk masing-masing lintasan seperti pada Gambar 11. 


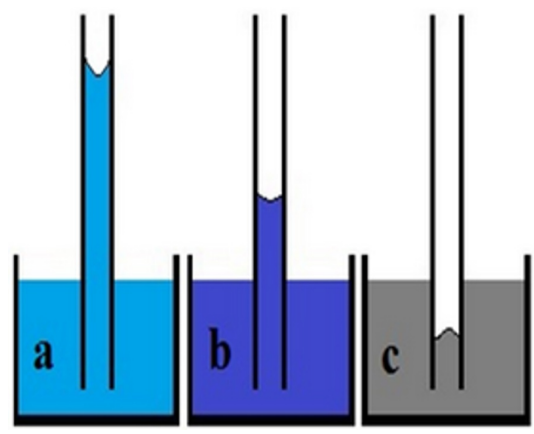

Gambar 9. Ilustrasi Tekanan Kapiler : (a) Tekanan Kapiler Besar (sudut kontak < 900), (b) Tekanan Kapiler Kecil (sudut kontak < 900), (c) Tekanan Kapiler Negatif (sudut kontak > 900)
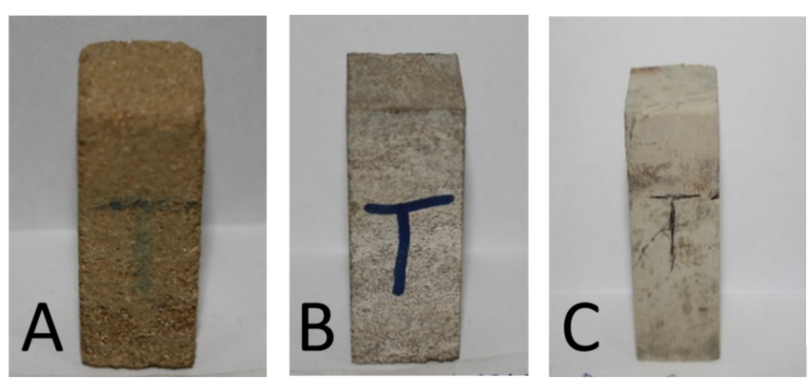

Gambar 10. Pengukuran Resistivitas Sampel Batuan. Resistivitas sample A ( Wet $=62$ ohm.m, Dry =330 ohm.m), Resistivitas sample B (Wet $=77$ ohm.m, Dry $=120$ ohm.m), Resistivitas sample C (Wet $=22$ ohm.m, Dry $=2800$ ohm.m).

Metode Wenner-Alpha lebih peka terhadap variasi lateral sehingga distribusi perubahan batuan arah sesar naik terlihat jelas namun memiliki penetrasi yang dangkal. Metode Wenner-Schlumberger memiliki penetrasi yang lebih dalam, tetapi kurang peka terhadap perubahan variasi arah lateral, oleh karena itu keberadaan sesar naik kurang tergambar secara jelas. Beberapa penulis melakukan studi juga bahwa Wenner-Alpha memiliki resolusi lateral yang lebih baik dan tidak peka noise, sedangkan Wenner-Schlumberger mempunyai kelebihan untuk penetrasi kedalaman (Dahlin dan Zhou, 2004; Okpoli, 2013; Szalai dkk., 2009).

Hasil inversi pengukuran metode tomografi resistivitas pada line 1 dan 2 menunjukkan terdapat struktur tegak (Trust fault) pada daerah survey. Struktur tegak yang berwarna merah pada Gambar 11 dan Gambar 15 diperkirakan adalah akuifer berlitologi napal atau akuifer napal jenuh air. Hal ini berdasarkan hasil pengukuran resistivitas di laboratorium, Nilai resistivitas batuan berkisar antara 22- $77 \mathrm{ohm}$.

Pada daerah penelitian ini, target akuifernya adalah reservoir napal karbonat pada Formasi Kerek berumur Miosen. Berdasarkan hasil survey dan studi yang kami lakukan, daerah ini terlihat memiliki kerumitan dan kompleksitas akuifer. Struktur perlapisannya didominasi lapisan tegak. Proses recharging zona akuifer dari air hujan dari strukturstruktur tegak ini yang memanjang secara regional dari arah barat dan timur. Air hujan akan sulit masuk dari zona dari sistem perlapisan yang mendatar dikarenakan dominasi lapisan berumur tua yang terdominasi lempung. Akumulasi air tanah serta kemudahan pengambilan air tanah di daerah ini ini dikontrol oleh efektifitas porositas dari batuan rese- rvoir karbonat napal ini, serta sistem kapilaritas dari batuan reservoir.

Pengukuran sudut kontak pada 2 sampel batuan napal yang diperoleh dari daerah penelitian, didapatkan sudut kontak Sampel A adalah 560, Sampel B adalah 640 (Gambar 12). Masing masing sampel masih memiliki sudut kontak kurang dari 900. Nilai sudut kontak ini menyimpulkan bahwa batuan napal akan sangat berpotensi menjadi akuifer yang jenuh air dikarenakan sudut kontaknya kurang dari 900 sehingga air dalam tanah akan cenderung dirambatkan keatas karena mekanisme kapilaritas. Batuan napal akan cenderung jenuh air atau menjadi akuifer yang baik meskipun struktur berarah tegak karena mekanisme Trust fault pada daerah ini.

Hasil pengukuran sudut kontak pada seluruh sampel napal selalu memiliki sudut kontak kurang dari 900 , oleh karenanya tekanan kapilernya selalu bernilai positif. Hal ini berarti batuan aquifer pada daerah penelitian ini dapat menaikkan air ke atas melalui rembesan sistem kapilaritas pada pori-pori batuan. Meskipun akuifer pada daerah penelitian ini memiliki struktur perlapisan yang didominasi lapisan tegak, tetapi memiliki kemungkinan terisi oleh air cukup banyak karena adanya tekanan kapiler positif pada akuifer ini.

Ilustrasi kondisi akuifer yang berada di daerah ini ditunjukkan pada Gambar 13. Thrust faulted zone di daerah ini menyebabkan akuifer air tanah membentuk struktur hampir tegak. Akuifer air tanah diperkirakan berupa lapisan napal karbonat yang memiliki porositas tinggi dan dicirikan dengan nilai resistivitas yang sedikit lebih tinggi. Masyarakat daerah ini mengambil air dengan menggali sumur tepat di akuifer napal yang dekat dengan permukaan seperti yang terlihat pada Gambar 14.

Pengambilan serta pengembangan air tanah kedepan untuk kebutuhan air bersih di daerah Sumber Lawang, Pegunungan Kendeng, Sragen ini bisa memanfaatkan pola akuifer bawah tanah yang diperlihatkan oleh penampang Tomografi resistivitas seperti pada Gambar 11 maupun sketsa akuifer seperti Gambar 13. Akuifer di daerah ini sangat mengandalkan fenomena fisika pada pori. Pengembangan kedepan sangat dianjurkan untuk melakukan pemboran yang bisa menembus sejumlah lapisan akuifer seperti pada Gambar 15.

\section{KESIMPULAN DAN SARAN}

Data pengukuran laboratorium, hasil survey dan serangkaian analisa yang kami lakukan menyimpulkan bahwa daerah sulit air di area studi ini masih memiliki potensi akuifer yang cukup baik. Metode tomografi resisitivitas berhasil mencitrakan sejumlah lokasi akuifer air tanah yang potensial meskipun didominasi lapisan dengan struktur-struktur berarah tegak.

Akuifer pada daerah ini berjenis napal karbonat yang dikelilingi oleh lapisan clay berumur Miosen yang impermeabel, namun hasil pengukuran sudut kontak yang selalu bersudut kecil menunjukkan bahwa air cenderung terangkat keatas. Fenomena ini menunjukkan bahwa sistem kapilaritas di akuifer napal karbonat Formasi Kerek ini mendukung untuk menjadi akuifer yang baik. Pengeboran akuifer di daerah ini disarankan agar menembus beberapa lapisan akuifer 


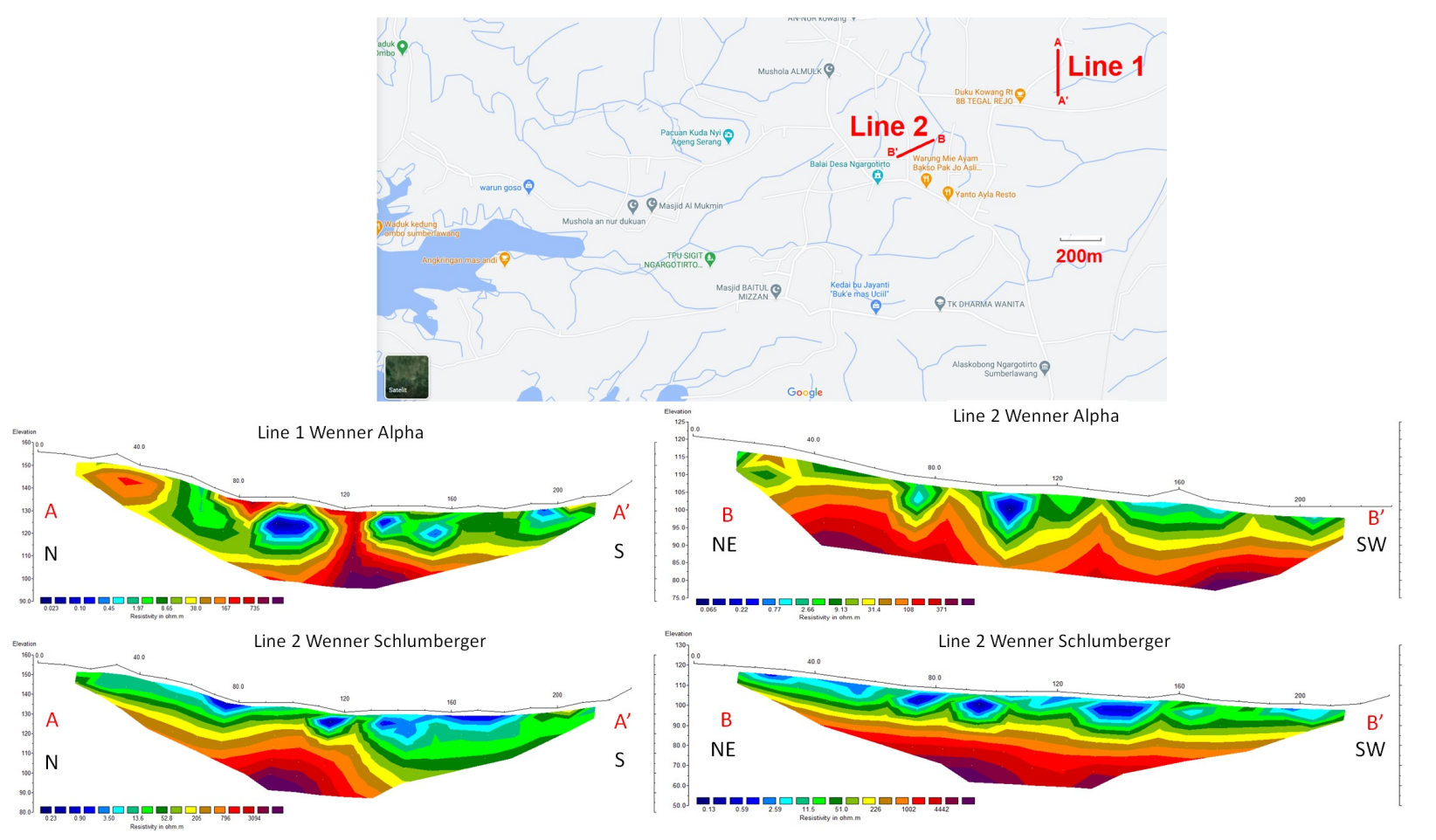

Gambar 11. Penampang Tomografi Resistivitas di line 1 dan di line 2.

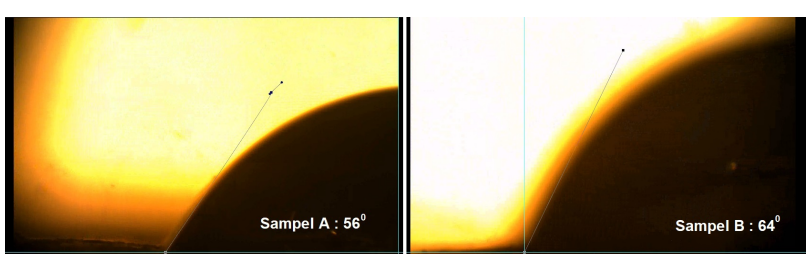

Gambar 12. Hasil Pengukuran Sudut Kontak Sampel Batuan Napal Formasi Kerek.

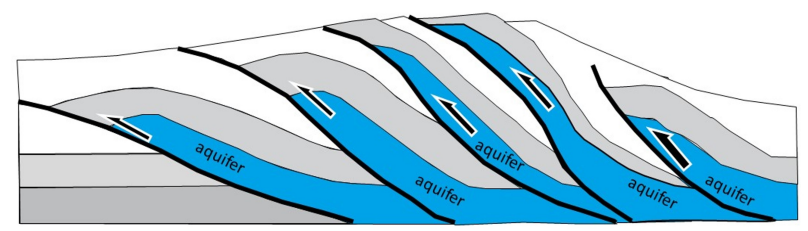

Gambar 13. Pola Penampang Akuifer Daerah Kendeng. Warna biru menunjukkan akuifer, warna abu-abu dan putih menunjukkan sketsa lapisan kaya lempung dan berumur tua.

seperti Gambar 15, sehingga dapat meningkatkan kapasitas produksi air sumur bor.

\section{Pustaka}

Arora, T. dan Ahmed, S. (2011): Characterization of recharge through complex vadose zone of a granitic aquifer by time-lapse electrical resistivity tomography. Journal of Applied Geophysics, 73(1), 35-44.

Bachmann, J., Deurer, M. dan Arye, G. (2007): Modeling water movement in heterogeneous water-repellent so-

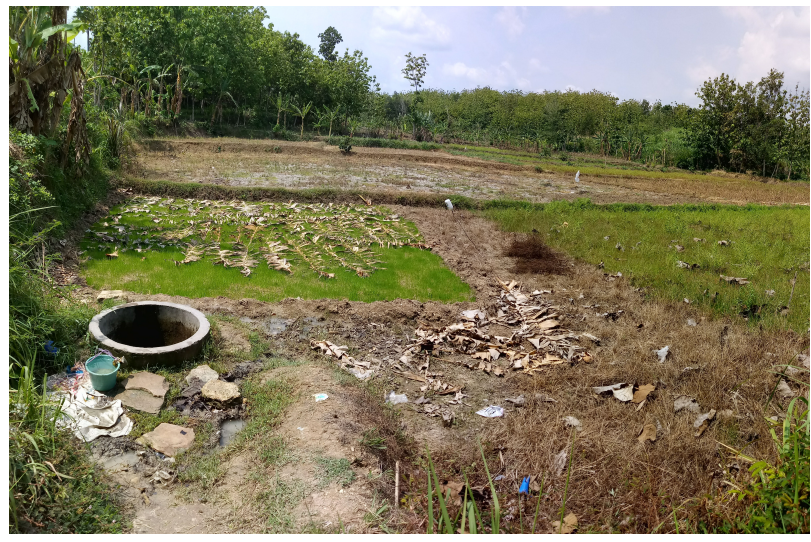

Gambar 14. Keadaan sumur untuk pengambilan air di akuifer Napal Formasi Kerek.

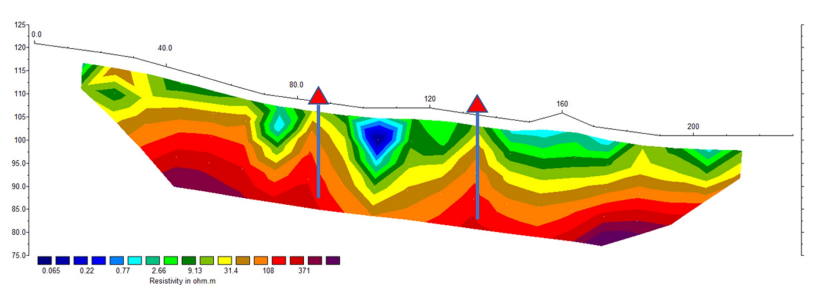

Gambar 15. Rekomendasi pengeboran untuk menghasilkan sumur dengan suplai air lebih besar.

il: 1. development of a contact angle-dependent waterretention model. Vadose Zone Journal, 6(3), 436-445. Bachmann, J., Horton, R., Van Der Ploeg, R. dan Woche, S. (2000): Modified sessile drop method for assessing ini- 
tial soil-water contact angle of sandy soil. Soil Science Society of America Journal, 64(2), 564-567.

BMKG (2021): Analisis curah hujan dan sifat hujan desember 2020. https://www.bmkg. go.id/iklim/informasi-hujan-bulanan.bmkg?p= analisis-curah-hujan-dan-sifat-hujan-desember-2020\& tag=\&lang=ID.

Dahlin, T. dan Zhou, B. (2004): A numerical comparison of $2 \mathrm{D}$ resistivity imaging with 10 electrode arrays. Geophysical Prospecting, 52(5), 379-398.

Daily, W., Ramirez, A., LaBrecque, D. dan Nitao, J. (1992): Electrical resistivity tomography of vadose water movement. Water Resources Research, 28(5), 1429-1442.

Gan, F., Han, K., Lan, F., Chen, Y. dan Zhang, W. (2017): Multi-geophysical approaches to detect karst channels underground-A case study in Mengzi of Yunnan Province, China. Journal of Applied Geophysics, 136, 91-98.

Kumar, D. dan Rai, S.T..S.N. (2011): Deciphering geothermal resources in Deccan trap region using electrical resistivity tomography technique. Journal of the Geological Society of India, 78, 541-548.

Martínez, J., Benavente, J., García-Aróstegui, J., Hidalgo, M. dan Rey, J. (2009): Contribution of electrical resistivity tomography to the study of detrital aquifers affected by seawater intrusion-extrusion effects: the river Vélez delta (Vélez-Málaga, southern Spain). Engineering geology, 108(3-4), 161-168.

Nurhandoko, B.E.B. (2018): Eksplorasi Air Bawah Tanah di Daerah Sulit Air untuk Sumber Air Minum dan Lahan Pertanian. LPPM ITB.

Nurhandoko, B.E.B. (2019a): Pendugaan Akuifer Air Tanah dan Pembuatan Instalasi Sumur Bor untuk Pemenuhan Kebutuhan Air Bersih Korban Gempa di Pulau Lombok Provinsi Nusa Tenggara Barat. LPPM ITB.

Nurhandoko, B.E.B. (2019b): Perangkat Pengukuran Tomografi Induced Polarization Resistivity Multichannel Nirkabel. Patent P0020190316, Dirjen HAKI Kemenkumham.

Nurhandoko, B.E.B., Asmarahadi, M.R., Sukrisna, B. dan Yasin, S. (2019): Subsurface resistivity tomography imaging of the 2018 Earthquake impacted areas in Lombok Island. Asian Physics Symposium 2019.

Okpoli, C.C. (2013): Sensitivity and resolution capacity of electrode configurations. International Journal of Geophysics, 2013.

Puradimaja, D.J., Nurhandoko, B.E.B. dan Priyono, I. (2006): Aliran airtanah pada sistim akifer Karst dan pendugaan dimensi gua dengan kombinasi metode geolistrik: inversi 2D dan Mise-a-la-masse. Studi Kasus: Kawasan Buniayu, Sukabumi, Jabar. Geoforum HAGI.

Redhaounia, B., Aktarakçi, H., Ilondo, B.O., Gabtni, H., Khomsi, S. dan Bédir, M. (2015): Hydro-geophysical interpretation of fractured and karstified limestones reservoirs: A case study from Amdoun region (NW Tunisia) using electrical resistivity tomography, digital elevation model (DEM) and hydro-geochemical approaches. Journal of African Earth Sciences, 112, 328-338.

Redhaounia, B., Ilondo, B.O., Gabtni, H., Sami, K. dan Bédir, M. (2016): Electrical resistivity tomography (ert) applied to karst carbonate aquifers: case study from amdoun, northwestern tunisia. Pure and Applied Geophysics, 173(4), 1289-1303.
Sukardi dan Budhitrisna, T. (1992): Peta Geologi Lembar Salatiga.

Szalai, S., Novák, A. dan Szarka, L. (2009): Depth of investigation and vertical resolution of surface geoelectric arrays. Journal of Environmental $\& 5$ Engineering Geophysics, 14(1), 15-23.

Tassy, A. dkk. (2014): Electrical resistivity tomography (ERT) of a coastal carbonate aquifer (Port-Miou, SE France). Environmental earth sciences, 71, 601-608.

Virman, V. dan Nurhandoko, B.E.B. (2016): Pemetaan lapisan akuifer Formasi Makats Daerah Tanah Hitam Distrik Abepura menggunakan metode geolistrik tahanan jenis. Wahana Fisika, 1, 87-98.

Wang, Z. dan Wallach, R. (2020): Effects of timedependent contact angle on wettability of subcritically water-repellent soils. Water Resources Research, 56(10), e2020WR027314. 